Review

\title{
Drug Treatment of Cancer Cell Lines: A Way to Select for Cancer Stem Cells?
}

\author{
Ilaria Chiodi, Cristina Belgiovine, Francesca Donà, A. Ivana Scovassi and Chiara Mondello * \\ Institute of Molecular Genetics, CNR, via Abbiategrasso 207, 27100 Pavia, Italy \\ * Author to whom correspondence should be addressed; E-Mail: mondello@igm.cnr.it; \\ Tel.: +39-0382-546332; Fax: +39-0382-422286.
}

Received: 4 January 2011; in revised form: 31 January 2011 / Accepted: 24 February 2011 / Published: 4 March 2011

\begin{abstract}
Tumors are generally composed of different cell types. In recent years, it has been shown that in many types of cancers a subset of cells show peculiar characteristics, such as the ability to induce tumors when engrafted into host animals, self-renew and being immortal, and give rise to a differentiated progeny. These cells have been defined as cancer stem cells (CSCs) or tumor initiating cells. CSCs can be isolated both from tumor specimens and established cancer cell lines on the basis of their ability to exclude fluorescent dyes, express specific cell surface markers or grow in particular culture conditions. A key feature of CSCs is their resistance to chemotherapeutic agents, which could contribute to the remaining of residual cancer cells after therapeutic treatments. It has been shown that CSC-like cells can be isolated after drug treatment of cancer cell lines; in this review, we will describe the strategies so far applied to identify and isolate CSCs. Furthermore, we will discuss the possible use of these selected populations to investigate CSC biology and develop new anticancer drugs.
\end{abstract}

Keywords: cancer; stem cells; drug resistance; chemotherapy

\section{The Cancer Stem Cells Concept}

Cancers are composed of heterogeneous cell populations, among which putative cancer stem cells (CSCs), or tumor initiating/propagating cells, have received a great deal of attention in recent years. Cancer stem cells are defined on the basis of three main characteristics: (1) a selective tumorigenic 
capacity; (2) self-renewal and differentiation, that is the ability to sustain growth of heterogeneous cancer tissues, being able to recreate the different populations observed in the tumor; (3) expression of specific surface markers, allowing their reproducible selection [1].

The theory of CSCs implies that a large number of tumor cells have to be injected into immunocompromised mice to get a tumor, because only a limited number of them is endowed with tumorigenic potential; in contrast, injection of very few "selected" CSCs would be sufficient to generate a tumor. Evidence supporting this concept was first obtained in hematological tumors, then in breast and brain cancers, followed by many other solid tumors [2-5]. Recent investigations have shown that the fraction of propagating tumor cells is not necessarily small, it can be very high as in melanoma [6], and can vary with the stage of malignant progression [7-9].

CSCs can be selected on the basis of the expression of a repertoire of surface markers, including CD44, CD24, CD133 and EPCAM (epithelial cell adhesion molecule) [10]; aldeyde dehydrogenase I (ALDHI) is a marker typically expressed in breast CSCs [11]. Another characteristic distinguishing tumor-initiating cells is the ability to exclude Hoechst 33342 dye. Dye excluding cells, named side population (SP), can be separated from the bulk of the tumor population by cell sorting. SPs isolated from different tumors showed a higher tumorigenic potential in immunocompromised mice compared to non-SP cells, suggesting that they were enriched in CSCs [12-15]. The SP phenotype is related to the overexpression of ATP-binding cassette $(\mathrm{ABC})$ transporters that can pump several types of endogenous and exogenous compounds out of the cell, including metabolites and drugs [16,17]. This phenotype can explain, at least in part, another important feature of CSCs: the high resistance to chemotherapeutic agents [18]. Chemoresistance and radioresistance have obvious implications for cancer treatment $[19,20]$ and can be additional markers for CSC selection, as will be deeply discussed in subsequent paragraphs of this review.

CSCs can also be selected from tumors through their ability to grow in spheres, also known as tumorspheres. This culture technique was originally developed to expand neuronal stem cells, when it was found that, from a single cell suspension, a small proportion of cells, representing undifferentiated multipotent neuronal cells, could grow in spheres in the absence of attachment to an exogenous substrate. In the spheres, between $4 \%$ and $20 \%$ of the cells were stem cells, while the others represented progenitor cells in different phases of differentiation [21,22]. Similarly, stem/progenitor cells were enriched from mammary cell populations on the basis of their ability to grow in spheres (mammospheres) [23]. Subsequently, sphere culture techniques were applied to cell populations from a variety of cancers, comprising brain cancers, colon cancers, breast cancers and melanoma, and successfully allowed the enrichment of cells with CSC features [24-30]. Spheres grown from breast cancer samples or breast cancer cell lines, for example, were more tumorigenic than the bulk of the population, showed an enrichment in $\mathrm{CD} 44^{+} / \mathrm{CD} 24^{-}$and SP cells, and a higher resistance to radiation $[23,29,30]$.

\section{CSC Origin}

The observation that some of the CSC features described above are shared with stem cells raised the hypothesis that CSCs derive from stem cells of the tissue in which the tumor develops. In myeloid leukemia, cells with tumorigenic potential express CD34 and are negative for $\mathrm{CD} 38\left(\mathrm{CD}^{+} 4^{+} / \mathrm{CD}^{-} 8^{-}\right)$, as well as normal blood cells characterized by the ability to repopulate the hematopoietic system of 
SCID (severe combined immunodeficient) mice, suggesting that tumor cells could derive from these precursors [3]. However, CSCs could also originate from differentiated cells that undergo dedifferentiation after the acquisition of oncogenic lesions and the engagement in neoplastic transformation.

To this regard, it is worth mentioning that terminally differentiated cells can be experimentally induced to acquire the pluripotency of embryonic stem cells (induced Pluripotent Stem-iPS-cells), clearly demonstrating that differentiated cells can undergo dedifferentiation [31,32]. Interestingly, some of the defined genes able to induce iPS cells are well-known oncogenes, or can be amplified in tumors (e.g., c-myc and SOX2) [31,33], while functional tumor suppressor genes, such as for example $p 16^{I N K 4 a}$, can be a barrier to dedifferentiation $[34,35]$. These observations indicate that tumor cells with stemness marks may indeed arise from differentiated cells after the acquisition of genetic lesions.

In support of this notion, it was shown that committed hematopoietic cells could undergo neoplastic transformation, becoming able to initiate and maintain leukemias, after exogenous expression of leukemogenic fusion proteins [36,37]. Moreover, cancer cells with stem-like properties were generated from pre-malignant mammary epithelial cells after transformation with activated oncogenes [38]. Cells with the ability to induce tumors in immunocompromised mice were also obtained from primary fibroblasts established in culture from skin biopsies, either after spontaneous neoplastic transformation [39], or after transformation with specific tumor genes [40]. Whether or not these transformed cell populations contained cells with a stem-like phenotype is not known; however, if they contained CS-like cells, it has to be argued that cells such as fibroblasts can acquire stemness markers during transformation, if they did not, it would mean that also cells devoid of stemness indicators can be endowed with tumorigenic potential.

In epithelial cancers, tumor progression and the acquisition of metastatic features are strongly connected with epithelial-mesenchymal transition (EMT) [41]. In the tumorigenic cell population obtained by Morel et al. [38] from pre-malignant breast cells, the stem cell-like phenotype was associated with features reminiscent of EMT, establishing a link between CSCs and EMT. In this line, evidence was reported that induction of EMT could generate cells with properties of stem cells $[42,43]$.

Taken together, the data reported so far suggest that there is a high degree of plasticity between CSCs and non-CSCs, with the possibility that CSCs generate non-CSCs and vice versa.

\section{CSCs, Drug Resistance and Cancer Cell Lines}

One of the main critical points in cancer treatment is the emergence of tumor recurrences after therapy. The high resistance to chemotherapeutic drugs of CSCs can be an important element in cancer relapse. If cancer therapies mainly target highly proliferating cells, it is likely that they can kill the bulk of tumors, rather than the CSCs, which are relatively quiescent and resistant to chemotherapeutic agents. A large body of evidence indicates that chemoresistance is associated with selection of more resistant CSCs and that more aggressive and refractory cancers contain more tumor-initiating cells $[25,44]$. Thus, future cancer therapies should combine agents able to target both non-CSCs and CSCs. Nevertheless, despite improving the fight against cancer by following this direction, it cannot be forgotten that tumor cells are genetically heterogeneous because of the accumulation of mutations and can undergo divergent clonal evolution [45]. This genetic instability must exist also in CSCs, which could thus present the same phenomenon observed in bulk tumor cell populations; that is the development of drug resistance [46]. 
Isolation of CSCs can be an important step for the validation of drugs directed against them. As mentioned in the first paragraph, CSCs can be isolated on the basis of specific surface marker repertoires, the ability to exclude fluorescent dyes or particular culture conditions; chemoresistance can be an additional tool to select CSCs. Selection can be performed both from tumor specimens and cancer cell lines.

Cancer cell lines can be established in vitro from tumor samples. Although it could be argued that during cancer cell line establishment, only CSCs emerge and give rise to the cell line, given the observation that only a limited number of cancer cells from a biopsy develop foci and grow [47], several studies have reported that only a fraction of cells in tumor cell lines exhibits a CSC phenotype [48]. How different cell populations can be maintained during culture propagation is matter of debate, because cells proliferating faster should out-compete cells with a lower growth rate; however, it might be that CSCs and non-CSCs are in reversible equilibrium and/or the more differentiated cells have a limited proliferation potential.

The first evidence that cancer cell lines grown in culture for many years contain cells with a CSC phenotype was obtained by Kondo et al. [49], who found that cell lines as diverse as glioma (C6), neuroblastoma (B104) and breast cancer (MCF7) cell lines and HeLa cells, all contained a small SP. Studying the C6 SP cells in more details, the authors found that their growth in the absence of serum, but in the presence of platelet-derived growth factor (PDGF) and basic fibroblast growth factor (bFGF), greatly enhanced the proportion of CS-like cells in the cell culture, with the formation of floating neurosphere-like aggregates. Moreover, C6 SP cells, but not non-SP C6 cells, were able to generate both SP and non-SP cells and to form tumors after injection into immunocompromised mice. Finally, C6 SP cells could differentiate both in neurons and glia, indicating that they had the characteristics of multipotent cells.

The analysis of phenotypic and genotypic traits of CSCs derived from glioblastoma cell lines grown in the presence of bFGF and epidermal growth factor revealed that they were more similar to primary tumors than cells grown in the presence of serum, indicating that CSC enriched populations could be a more reliable tool to study the biology of primary tumors than cell lines in toto [50].

CS-like cells were also isolated on the basis of specific CSC features from cell lines established from different types of tumors [49-65] (a review of CSCs derived from cancer cell lines is presented in Table 1, together with the isolation methods and their main features). Sajithlal et al. [60] developed an original approach to isolate CSCs from human breast cancer cell lines. These authors tagged four breast cancer cell lines with the green fluorescent protein (GFP) under the control of the OCT3/4 stem cell-specific promoter; the GFP-positive populations were highly enriched in cells with CSC features and gave rise to tumors when injected into immunocompromised mice. Interestingly, almost all tumor derived cells displayed CSC characteristics, suggesting that the OCT3/4 promoter blocked CSC differentiation, with a mechanism unknown so far, consenting to obtain stable CSC lines, highly useful for further investigations. Long-term cultures of CS-like cells from breast cancer cell lines could be established, confirming the relevance of tumor cell lines to study cancer initiating cells [29]. 
Table 1. Cancer stem cell (CSC) selection from tumor cell lines.

\begin{tabular}{|c|c|c|c|c|}
\hline Cell line & Cancer & Selection method & Characteristics of isolated CSCs & Reference \\
\hline C6 & rat glioma & SP * sorting & $\begin{array}{l}\text { increased expression of bFGF and PDGF } \\
\text { increased invasion ability }\end{array}$ & [49] \\
\hline $\begin{array}{l}\text { MCF7, } \\
\text { BT474, }\end{array}$ & breast & sphere formation & increased expression of stemness markers ${ }^{\S}$ & {$[54]$} \\
\hline 734B & & & $\begin{array}{l}\text { increased tumor-initiation ability } \\
\text { karyotype alterations }\end{array}$ & \\
\hline A549 & lung & sphere formation & $\begin{array}{l}\text { increased expression of stemness markers } \\
\text { increased tumor-initiation ability } \\
\text { karyotype alterations }\end{array}$ & {$[54]$} \\
\hline Cal-51 & breast & SP sorting & $\begin{array}{l}\text { increased expression of mammary } \\
\text { epithelial markers }\end{array}$ & {$[52]$} \\
\hline SKBR3 & breast & sphere formation & reduced let7 expression & {$[51]$} \\
\hline SKOV-3 & ovary & sphere formation & $\begin{array}{l}\text { increased expression of stemness markers } \\
\text { increased tumor-initiation ability } \\
\text { karyotype alterations }\end{array}$ & {$[54]$} \\
\hline $3 \mathrm{AO}$ & ovary & sphere formation & $\begin{array}{l}\text { increased expression of stemness markers } \\
\text { increased tumor-initiation ability } \\
\text { drug resistance }\end{array}$ & {$[61]$} \\
\hline JR8 & melanoma & sphere formation & $\begin{array}{l}\text { increased expression of stemness markers } \\
\text { increased tumor-initiation ability } \\
\text { karyotype alterations }\end{array}$ & {$[54]$} \\
\hline $\begin{array}{l}\text { Me204ADH, } \\
\text { JR8ADH, } \\
\text { Me14346ADH }\end{array}$ & melanoma & sphere formation & $\begin{array}{l}\text { increased expression of stemness markers } \\
\text { increased tumor-initiation ability }\end{array}$ & {$[59]$} \\
\hline SW480 & colorectal & stemness markers & $\begin{array}{l}\text { increased expression of stemness markers } \\
\text { increased expression of metastatic markers } \\
\text { high metastatic ability }\end{array}$ & {$[56]$} \\
\hline \multirow[t]{2}{*}{$\begin{array}{l}\text { HCT116, } \\
\text { HT29 }\end{array}$} & colorectal & stemness markers & increased expression of stemness markers & {$[62]$} \\
\hline & & & $\begin{array}{l}\text { increased tumor-initiation ability } \\
\text { increased invasion ability } \\
\text { change in morphology }\end{array}$ & \\
\hline SK-ES-1 & Ewing sarcoma & SP sorting & $\begin{array}{l}\text { increased expression of stemness markers } \\
\text { increased invasion ability } \\
\text { increased proliferation rate } \\
\text { increased colony-forming ability } \\
\text { drug resistance }\end{array}$ & {$[65]$} \\
\hline $\begin{array}{l}\text { Hu9, MG63 } \\
\text { OS99-1, } \\
\text { SaOS-3 }\end{array}$ & osteosarcoma & sphere formation & increased expression of stemness markers & {$[64]$} \\
\hline MG63 & osteosarcoma & ALDH expression & $\begin{array}{l}\text { drug resistance } \\
\text { increased sphere formation }\end{array}$ & {$[55]$} \\
\hline
\end{tabular}


Table 1. Cont.

\begin{tabular}{|c|c|c|c|c|}
\hline Cell line & Cancer & Selection method & Characteristics of isolated CSCs & Reference \\
\hline HPET & prostate & stemness markers & $\begin{array}{l}\text { increased expression of stemness markers } \\
\text { drug resistance }\end{array}$ & {$[53]$} \\
\hline SK-RC-42 & kidney & sphere formation & $\begin{array}{l}\text { increased expression of stemness markers } \\
\text { increased tumor-initiation ability } \\
\text { reduced proliferation rate } \\
\text { reduced immune-system stimulation } \\
\text { drug/radio resistance }\end{array}$ & {$[63]$} \\
\hline HT1080 & fibrosarcoma & ALDH expression & increased sphere formation & {$[55]$} \\
\hline SMS-KCN & neuroblastoma & SP sorting & increased expression of stemness markers & {$[58]$} \\
\hline SMS-KAN & & & increased proliferation rate & \\
\hline CHLA-122 & & & increased colony-forming ability & \\
\hline
\end{tabular}

\section{CSC Selection from Cancer Cell Lines after Drug Treatment}

Although CSCs were originally described in myeloid leukemia [3], their separation from leukemic cells isolated from patients still represents a problem, due to their scarcity and the possible contamination with normal hematopoietic stem cells (HSCs). It has been recently reported that leukemic CSCs (LSCs, leukemic stem cells) can be easily enriched from leukemic cell lines through drug selection. Given that some features of LSCs are similar to those of normal HSCs, an isolation strategy taking advantage of this peculiarity was envisaged. A protocol originally developed to isolate HSCs was applied to the human leukemic cell line KG1a; this method is based on the fact that HSCs and LCSs are quiescent and thus insensitive to drugs acting on proliferating cells, such as the pyrimidine antagonist 5-fluorouracil (5-FU). By incubating KGla cells with 5 -FU ( $50 \mu \mathrm{g} / \mathrm{mL}$ for 4 days), a KG1a CD $34^{+} / \mathrm{CD} 8^{-}$cell subpopulation, corresponding to $\mathrm{CSCs}$, was isolated and further characterized with respect to CSC markers. The population was enriched in Hoechst 33342-excluding cells, showed a proliferative potential in vitro after drug removal and a low level of RNA synthesis, consistent with a quiescent state. Moreover, these cells showed a higher expression of the transporter ABCG2 compared to the progenitor cells [66]. This latter feature, alteration in ABC transporters, is not exclusive to CSCs, being a hallmark of drug-resistance [67].

Isolation of CSCs through drug selection has also been applied to numerous solid cancer cell lines. Breast cancer still represents a major health issue worldwide. So far, different strategies based on single step or prolonged incubation of breast cancer cell lines with drugs have been developed for the isolation of breast CSCs. Calcagno et al. [68] demonstrated that long-term exposure of the MCF7 breast cancer cell line to increasing concentrations of doxorubicin not only selected for resistant cells (MCF-7/ADR), but also for cells with a stem-like phenotype, being the $\mathrm{CD}_{4} 4^{+} / \mathrm{CD} 24^{-}$population highly enriched among resistant cells. Microarray analysis of global gene expression profiles of parental cells compared to the doxorubicin-resistant subline identified not only a panel of drug-resistance overexpressed genes, as expected, but also a stem-like gene expression profile in 
MCF-7/ADR cells. Furthermore, these cells formed mammospheres, were more invasive and more tumorigenic in mice than parental cells. Interestingly, drug resistant cells showed typical features of cells that have undergone an epithelial-mesenchymal transition, confirming the parallelism between CSC phenotype and EMT. Although these observations should be confirmed studying additional drug resistant tumor cell populations, they suggest that prolonged drug treatment of breast cancer patients may result in the selection of chemotherapy-resistant cells with a CSC phenotype, which might be true cancer stem cells.

An intriguing approach to isolate CSCs from the human breast cancer cell line MCF-7 was recently applied, consisting of the use of nicotine; this compound was tested on breast cancer cell lines with the aim of investigating whether smoking could increase breast cancer risk [69]. Using a concentration of nicotine closely related to the blood concentration in cigarette smokers (10 $\mathrm{nM}-10 \mu \mathrm{M})$, an increase in stem cell population, identified as $\mathrm{ALDH}^{+}$cells, was observed in MCF7 cells. This population forming mammospheres was characterized with respect to Notch signaling, which is involved in anchorageindependent growth [70]. It was found that the Notch pathway was activated in $\mathrm{ALDH}^{+}$cells through a kinase cascade. This evidence could discourage ladies from smoking!

About $20 \%$ of breast cancers are characterized by the Her-2 oncogene amplification (and the consequent overexpression of the HER2 protein), which is associated with an aggressive disease and early development of metastasis [71,72]. HER $2^{+}$patients are usually treated with trastuzumab (Herceptin ${ }^{\circledR}$; Genentech Inc., San Francisco, CA, USA), a human monoclonal antibody directed to the extracellular domain of HER2, which induces antibody-dependent cell-mediated cytotoxicity in tumor cells [73]. However, it is now clear that after an initial promising response, very often tumor cells acquire immunoresistance and cancer relapses [74]. Among the many reasons for this deleterious phenomenon [75-78], the possible selection of CSCs by trastuzumab was taken into account. To address this point, immunoresistant cells were isolated from human breast cancer cell lines treated with trastuzumab, and further characterized with respect to CSC markers [79]. Cells preferentially surviving the treatment showed the ability to grow in spheres, increased clonogenicity in vitro and tumorigenicity in vivo; moreover, they displayed a CD $44^{\text {high }} / \mathrm{CD} 24^{\text {low }} \mathrm{CSC}$-like phenotype. HER2 was still expressed in selected cells, although at a lower level compared to parental cells, indicating that immunotherapy resistance was not due to lack of HER2 expression and that HER2 has probably a role in the maintenance of breast CSCs [80]. Sorting and further culturing of CD $44^{\text {high }} / \mathrm{CD} 24^{\text {low }}$ cells revealed that they could revert to the original CD $44^{\text {high }} / \mathrm{CD} 24^{\text {high }}$ phenotype, confirming their CSC-like nature and indicating that the immunoselection process actually selected for CSCs. When immunoselected MCF7 cells were expanded in culture, they were still enriched in CD $44^{\text {high }} / \mathrm{CD} 24^{\text {low }}$ but showed a higher expression of HER2; this evidence suggests that treatment with anti-HER2 antibodies of tumors that initially showed a good response could still be beneficial after relapse [79].

To deeper characterize metastatic breast cancers, the relevance of hypoxia, which is a critical factor to promote invasive tumor growth, has been addressed by developing a protocol to expose human breast cancer metastatic cell lines to repetitive cycles of hypoxia-reoxygenation [57]. Under these conditions, which mimic the situation occurring in vivo during tumor development and metastatic property acquisition, the authors observed that a cycling cell subpopulation could be expanded, having a stem-like phenotype. Moreover, these microenvironment-selected cells were able to form colonies readily, to induce tumors in immunocompromised mice and exhibited an EMT phenotype. These 
observations suggest that a stem-like subpopulation in the tumor could expand selectively in response to changes in the microenvironment. The possibility to use niche factors in the tumor microenvironment to select CSCs from cancer cell lines opens up new chances to study and characterize these cells.

As for another hormone-dependent tumor, that is ovarian cancer, a strategy for isolating and propagating CSCs through drug selection has been recently described [81]. Employing cisplatin and paclitaxel, two widely used chemotherapeutic drugs, a subpopulation forming non adherent spheres was isolated from the human ovarian cancer cell line SKOV3 and characterized with respect to tumorigenic potential, expression of cell surface antigens and of a panel of stem cell genes by microarray analysis. The self-renewing isolated sphere cells were found to display stem cell properties, (expressing high levels of several stem cell genes, such as Nanog, Oct4, sox2, nestin, ABCG2, CD133 and CD117), to be highly tumorigenic and, remarkably, resistant not only to cisplatin and paclitaxel but also to adriamycin and methotrexate. This latter feature renders them a suitable tool to test chemotherapeutic protocols in order to identify an efficient strategy to kill them. In fact, as recently reviewed [82], CSC isolation and characterization from ovarian cancer is extremely important for defining the therapy against this malignancy still representing the most fatal gynecological disease. In particular, the isolation of ovarian CSCs may facilitate the search for the mechanism(s) of intrinsic drug resistance, possibly due to many factors, including resistance to apoptosis, altered drug efflux, quiescence and proneness to tumor progression [82].

Prostate cancer, another hormone-mediated tumor, can be promoted by chronic exposure to arsenic, a carcinogen that attacks the urogenital system [83]. Chronic in vitro exposure of human prostate cells to inorganic arsenic can induce their malignant transformation [84]. Studying arsenite-induced transformation of the RWPE-1 normal prostate cell line, Tokar et al. [85] showed that arsenite resistant cells were enriched in cells with stem cell features, such as the ability to grow as spheres, hyperexpression of anti-apoptotic proteins, as Bcl2, MT1 and MT2, and low expression of proapoptotic Bax and apoptotic caspases. Moreover, CSC-like/arsenite-resistant cells were altered in drug efflux, having an intrinsic high expression of the ABCC1 and GSTP1 genes. Since normal prostate stem cells are intrinsically more resistant to arsenite than mature cells, it was hypothesized that drug exposure could select for stem cells present in the population, which could in turn be more keen to undergo malignant transformation.

Going deeper into drug selection of CSCs, Levina et al. [86] characterized drug surviving cells (DSCs) after exposure of the H460 human lung cancer cell line to etoposide, cisplatin or doxorubicin. DSCs were enriched in SP cells, expressed several stem cell markers (e.g., CD133, CD117, OCT4 and nuclear $\beta$-catenin, which is believed to be a key player in stem cell self-renewal capacity), and had lost the expression of differentiation markers, such as cytokeratins 8/18. Moreover, DSCs were able to grow as spheres, and maintained the capacity of self-renewal and to differentiate. However, upon differentiation, cells lost stem cell features and acquired drug sensitivity, while growth in the presence of drugs prevented differentiation, thus preserving the enrichment in CSCs of the population.

These observations suggest that chemotherapy increases the proportion of CSCs and eliminates the more differentiated tumor cells. In the classical chemotherapeutic plan, consisting of drug administration in several cycles separated by three-week intervals, differentiated cells could be possibly restored during the period in the absence of the drug. However, although differentiated tumor cells are drug sensitive, a population exposed to drugs contains a higher proportion of CSCs than the 
original population, therefore subsequent chemotherapy cycles could lead to tumors more and more enriched in resistant CSCs, rendering hard to eradicate cancer.

Another important result obtained by characterizing CSCs isolated after drug selection of H460 lung cancer cells was the understanding of some of the CSC properties that make these cells highly tumorigenic and metastatic [86]. By comparing sonicated lysates of parental and CSC tumors generated in mice, Levina et al. [86] showed that CSC-derived tumors produced higher levels of cytokines, chemokines, angiogenic and growth factors, which could mediate autocrine and paracrine signals giving rise to tumor cell proliferation and migration. In particular, CSCs expressed two-to-three fold higher levels of angiogenic and growth factors such as VEGF, PDGF-VV, bFGF, IGFBP- $\beta$ and $\mathrm{HGF}$, as well as higher levels of VEGFR1 and FGFR2 receptors. Moreover, CSC-derived tumors contained increased levels of cytokine IL-6 and chemokine IL-8, together with high levels of IL-8 receptors CXCR1 and CXCR2. Chemokines and growth factors produced by tumor cells, binding to their cognate receptors on tumor and stroma cells, could provide proliferative and anti-apoptotic signals helping tumor cells to resist to chemotherapeutic treatments.

In this respect, it has been recently reported [87] that a subpopulation of breast CSCs overexpressed the IL-8 receptor CXRC1 and selective CXRC1 blockade in two breast cancer cell lines, by means of specific antibodies or of the small molecule inhibitor repertaxin, affected the proliferation of CSCs in vitro and in nude mice, where tumor development and metastasis formation were delayed [88]. Of note, CSCs lacking CXRC1 expression were able to undergo apoptosis via the activation of FasL/Fas signaling.

The poor prognosis of patients with glioma prompted many groups to investigate the nature of chemotherapy-resistance of this aggressive tumor. Temozolomide, a DNA alkylating agent that blocks cell cycle at the $\mathrm{G}_{2} / \mathrm{M}$ phase, is widely used in clinics against brain aggressive tumors [89]. Exposure of U87MG and T98G glioma cells to DNA-damaging and clinically relevant doses of temozolomide led to the selection from each cell line of populations in which SP cells were increased 8- and 5-fold, respectively [90]. These SP cells showed tumor initiating potential and overexpression of ABCG2, as well as of other drug transporters. Moreover, in SP cells after temozolomide treatment, the percentage of cells co-staining for Msi-1, a marker for self-renewal [91], and ABCG2 was increased, suggesting that ABCG2 expression in CSCs with self-renewal capability could be important for drug efflux, and thus for drug resistance. Interestingly, ABCG2 knockdown did not abrogate the SP response to temozolomide, suggesting that other drug transporters could be activated leading to chemoresistance. On the basis of these results, it can be speculated that cancer recurrence could contain SP cells selected in vivo after temozolomide treatment for the expression of a drug-resistance gene. Preliminary data reported by Chua et al. [90] indicated that the percentage of SP cells was actually greater in a patient with recurrent glioblastoma multiforme than in a patient with no history of chemotherapy or radiotherapy.

The isolation of CSCs from the glioblastoma U251 cell line was obtained through the treatment with the chemotherapeutic drug etoposide. After etoposide exposure, U251 CS-like cells showed a greater resistance to apoptosis and death than the bulk of the tumor cell population [92].

Within the frame of a frantic active search for new and innovative compounds potentially acting as chemotherapeutic drugs, it has been recently reported that the use of pharmacological inhibitors of poly(ADP-ribosylation) could represent a novel therapeutic strategy to kill cancer cells as well as to attenuate the inflammatory processes that characterize many disorders [93-95]. Indeed, powerful protocols based on the pharmacological inhibition of PARP (poly(ADP-ribose) polymerase) enzymes 
are already adopted in clinical medicine especially to cure BRCA-deficient cancers [96]. However, the long-term effects of such drugs remain to be fully explored; a cautionary note originates from the fact that PARP enzymes are actively involved in DNA repair, thus the inhibition of their activity could impair the damage response [97,98]. In this respect, it has been recently shown that prolonged (100 days) incubation of human osteosarcoma MG-63 cells with 3-aminobenzamide (3-AB), a classic poly (ADP-ribosylation) inhibitor, resulted in the irreversible selection (even after 73 passages) of 3-AB-resistant cell population with stem cell features, such as ability to form sarcospheres, high drug efflux capacity, and stem cell surface marker expression. Of note, these cells acquired the ability to grow indefinitely, possibly because of telomerase activation, and expressed high levels of the Hif- $1 \alpha$ protein, which is involved in managing cancer hypoxic microenvironment [99]. This approach, based on the use of 3-AB, could be applied to other cancer model systems, in order to explore the possible selection of CSCs through the inhibition of DNA repair cellular functions.

As for the treatment of recurrent cancers, there is a strong interest towards naturally occurring plantbased remedies and dietary factors, which could represent an alternative to conventional chemotherapy [100]. However, sometimes their beneficial effects could not be associated to a precise mechanism of action, thus making it difficult to manage their use. Natural compounds have been tested for their ability to target the CSC population isolated from cancer cell lines [101]. For example, curcumin, which has multiple beneficial effects on health [102], proved to reduce the SP fraction in rat C6 glioma cells, thus suggesting its potential use in brain tumor treatment [103]. These data are in line with previous reports on the effect of other plant compounds, such as parthenolide [104,105], berberine [106] and cyclopamine [107], found to be active on CSCs. Of course, further experiments are needed to confirm this evidence and to define the phenotypic parameters affected by phytochemicals. Among non-toxic agents possibly targeting cancer stem cells, it is worthwhile mentioning metformin, an anti-diabetic drug, which selectively targets breast cancer stem cells and, used in combination with chemotherapeutic agents, blocks tumor growth and prolongs remission [108,109].

\section{Conclusions and Future Perspectives}

Standard chemotherapy kills most of the cells in a tumor; however, some cells can survive and may cause tumor recurrence, even several years after treatment of the first tumor. A large body of evidence indicates that these cells could be the CS/tumor initiating cells, which are therefore a very important target for chemotherapy. Although CSC research is still in its infancy and many questions are still open, the isolation and further characterization of CSCs opened up new perspectives in clinical oncology. It is clear by now that cells with CSC features can be isolated from cancer cell lines; this is an important chance to study CSCs because of the high number of cells that can be obtained from cell lines, suitable for extensive molecular investigations and the analysis of cellular features, including growth parameters, tumorigenic potential, and drug sensitivity. Isolation of CSCs from cancer cell lines after treatment with drugs can mimic what happens in vivo during chemotherapy, thus making selected cells particularly appropriate to investigate drug resistance mechanisms and test new therapeutic agents. A future challenge for the use of in vitro cultured CSCs will be the development of culture conditions favoring the maintenance of their stem-like properties and, ideally, simulating the growth and differentiation inhibitory signaling provided by the microenvironment. Moreover, further 
investigations on CSC genome instability and evolution during cancer progression will have to be carried out, to design new therapeutic strategies that could be appropriate to counteract the development of drug resistance.

\section{Acknowledgements}

C.B. is a PhD student of the University of Pavia (Dottorato in Scienze Genetiche e Biomolecolari). F.D. is supported by Regione Lombardia (ATP Project Plant Cell).

\section{References}

1. Reya, T.; Morrison, S.J.; Clarke, M.F.; Weissman, I.L. Stem cells, cancer, and cancer stem cells. Nature 2001, 414, 105-111.

2. Lapidot, T.; Sirard, C.; Vormoor, J.; Murdoch, B.; Hoang, T.; Caceres-Cortes, J.; Minden, M.; Paterson, B.; Caligiuri, M.A.; Dick, J.E. A cell initiating human acute myeloid leukaemia after transplantation into SCID mice. Nature 1994, 367, 645-648.

3. Bonnet, D.; Dick, J.E. Human acute myeloid leukemia is organized as a hierarchy that originates from a primitive hematopoietic cell. Nat. Med. 1997, 3, 730-737.

4. Al-Hajj, M.; Wicha, M.S.; Benito-Hernandez, A.; Morrison, S.J.; Clarke, M.F. Prospective identification of tumorigenic breast cancer cells. Proc. Natl. Acad. Sci. USA 2003, 100, 3983-3988.

5. Hermann, P.C.; Bhaskar, S.; Cioffi, M.; Heeschen, C. Cancer stem cells in solid tumors. Semin. Cancer Biol. 2010, 20, 77-84.

6. Quintana, E.; Shackleton, M.; Sabel, M.S.; Fullen, D.R.; Johnson, T.M.; Morrison, S.J. Efficient tumour formation by single human melanoma cells. Nature 2008, 456, 593-598.

7. Chiou, S.H.; Yu, C.C.; Huang, C.Y.; Lin, S.C.; Liu, C.J.; Tsai, T.H.; Chou, S.H.; Chien, C.S.; Ku, H.H.; Lo, J.F. Positive correlations of Oct-4 and Nanog in oral cancer stem-like cells and high-grade oral squamous cell carcinoma. Clin. Cancer. Res. 2008, 14, 4085-4095.

8. Harris, M.A.; Yang, H.; Low, B.E.; Mukherjee, J.; Guha, A.; Bronson, R.T.; Shultz, L.D.; Israel, M.A.; Yun, K. Cancer stem cells are enriched in the side population cells in a mouse model of glioma. Cancer Res. 2008, 68, 10051-10059.

9. Thon, N.; Damianoff, K.; Hegermann, J.; Grau, S.; Krebs, B.; Schnell, O.; Tonn, J.C.; Goldbrunner, R. Presence of pluripotent CD133+ cells correlates with malignancy of gliomas. Mol. Cell. Neurosci. 2010, 43, 51-59.

10. Maenhaut, C.; Dumont, J.E.; Roger, P.P.; van Staveren, W.C. Cancer stem cells: a reality, a myth, a fuzzy concept or a misnomer? An analysis. Carcinogenesis 2010, 31, 149-158.

11. Ginestier, C.; Hur, M.H.; Charafe-Jauffret, E.; Monville, F.; Dutcher, J.; Brown, M.; Jacquemier, J.; Viens, P.; Kleer, C.G.; Liu, S.; et al. ALDH1 is a marker of normal and malignant human mammary stem cells and a predictor of poor clinical outcome. Cell Stem Cell 2007, 1, 555-567.

12. Hirschmann-Jax, C.; Foster, A.E.; Wulf, G.G.; Nuchtern, J.G.; Jax, T.W.; Gobel, U.; Goodell, M.A.; Brenner, M.K. A distinct "side population" of cells with high drug efflux capacity in human tumor cells. Proc. Natl. Acad. Sci. USA 2004, 101, 14228-14233. 
13. Haraguchi, N.; Utsunomiya, T.; Inoue, H.; Tanaka, F.; Mimori, K.; Barnard, G.F.; Mori, M. Characterization of a side population of cancer cells from human gastrointestinal system. Stem Cells 2006, 24, 506-513.

14. Ho, M.M.; Ng, A.V.; Lam, S.; Hung, J.Y. Side population in human lung cancer cell lines and tumors is enriched with stem-like cancer cells. Cancer Res. 2007, 67, 4827-4833.

15. Zhang, P.; Zhang, Y.; Mao, L.; Zhang, Z.; Chen, W. Side population in oral squamous cell carcinoma possesses tumor stem cell phenotypes. Cancer Lett. 2009, 277, 227-234.

16. Schinkel, A.H.; Jonker, J.W. Mammalian drug efflux transporters of the ATP binding cassette (ABC) family: an overview. Adv. Drug Deliv. Rev. 2003, 55, 3-29.

17. Ding, X.W.; Wu, J.H.; Jiang, C.P. ABCG2: a potential marker of stem cells and novel target in stem cell and cancer therapy. Life Sci. 2010, 86, 631-637.

18. Zhou, B.B.; Zhang, H.; Damelin, M.; Geles, K.G.; Grindley, J.C.; Dirks, P.B. Tumour-initiating cells: Challenges and opportunities for anticancer drug discovery. Nat. Rev. Drug Discov. 2009, 8, 806-823.

19. Baumann, M.; Krause, M.; Thames, H.; Trott, K.; Zips, D. Cancer stem cells and radiotherapy. Int. J. Radiat. Biol. 2009, 85, 391-402.

20. Sengupta, A.; Cancelas, J.A. Cancer stem cells: a stride towards cancer cure? J. Cell. Physiol. 2010, 225, 7-14.

21. Reynolds, B.A.; Weiss, S. Clonal and population analyses demonstrate that an EGF-responsive mammalian embryonic CNS precursor is a stem cell. Dev. Biol. 1996, 175, 1-13.

22. Weiss, S.; Dunne, C.; Hewson, J.; Wohl, C.; Wheatley, M.; Peterson, A.C.; Reynolds, B.A. Multipotent CNS stem cells are present in the adult mammalian spinal cord and ventricular neuroaxis. J. Neurosci. 1996, 16, 7599-7609.

23. Dontu, G.; Abdallah, W.M.; Foley, J.M.; Jackson, K.W.; Clarke, M.F.; Kawamura, M.J.; Wicha, M.S. In vitro propagation and transcriptional profiling of human mammary stem/progenitor cells. Genes Dev. 2003, 17, 1253-1270.

24. Singh, S.K.; Clarke, I.D.; Terasaki, M.; Bonn, V.E.; Hawkins, C.; Squire, J.; Dirks, P.B. Identification of a cancer stem cell in human brain tumors. Cancer Res. 2003, 63, 5821-5828.

25. Singh, S.K.; Hawkins, C.; Clarke, I.D.; Squire, J.A.; Bayani, J.; Hide, T.; Henkelman, R.M.; Cusimano, M.D.; Dirks, P.B. Identification of human brain tumour initiating cells. Nature 2004, 432, 396-401.

26. Galli, R.; Binda, E.; Orfanelli, U.; Cipelletti, B.; Gritti, A.; De Vitis, S.; Fiocco, R.; Foroni, C.; Dimeco, F.; Vescovi, A. Isolation and characterization of tumorigenic, stem-like neural precursors from human glioblastoma. Cancer Res. 2004, 64, 7011-7021.

27. Yuan, X.; Curtin, J.; Xiong, Y.; Liu, G.; Waschsmann-Hogiu, S.; Farkas, D.L.; Black, K.L.; Yu, J.S. Isolation of cancer stem cells from adult glioblastoma multiforme. Oncogene 2004, 23, 9392-9400.

28. Fang, D.; Nguyen, T.K.; Leishear, K.; Finko, R.; Kulp, A.N.; Hotz, S.; Van Belle, P.A.; Xu, X.; Elder, D.E.; Herlyn, M. A tumorigenic subpopulation with stem cell properties in melanomas. Cancer Res. 2005, 65, 9328-9337.

29. Ponti, D.; Costa, A.; Zaffaroni, N.; Pratesi, G.; Petrangolini, G.; Coradini, D.; Pilotti, S.; Pierotti, M.A.; Daidone, M.G. Isolation and in vitro propagation of tumorigenic breast cancer cells with stem/progenitor cell properties. Cancer Res. 2005, 65, 5506-5511. 
30. Phillips, T.M.; McBride, W.H.; Pajonk, F. The response of CD24(-/low)/CD44+ breast cancer-initiating cells to radiation. J. Nat. Cancer Inst. 2006, 98, 1777-1785.

31. Takahashi, K.; Yamanaka, S. Induction of pluripotent stem cells from mouse embryonic and adult fibroblast cultures by defined factors. Cell 2006, 126, 663-676.

32. Takahashi, K.; Tanabe, K.; Ohnuki, M.; Narita, M.; Ichisaka, T.; Tomoda, K.; Yamanaka, S. Induction of pluripotent stem cells from adult human fibroblasts by defined factors. Cell 2007, 131, 861-872.

33. Bass, A.J.; Watanabe, H.; Mermel, C.H.; Yu, S.; Perner, S.; Verhaak, R.G.; Kim, S.Y.; Wardwell, L.; Tamayo, P.; Gat-Viks, I.; et al. SOX2 is an amplified lineage-survival oncogene in lung and esophageal squamous cell carcinomas. Nat. Genet. 2009, 41, 1238-1242.

34. Banito, A.; Rashid, S.T.; Acosta, J.C.; Li, S.; Pereira, C.F.; Geti, I.; Pinho, S.; Silva, J.C.; Azuara, V.; Walsh, M.; Vallier, L.; Gil, J. Senescence impairs successful reprogramming to pluripotent stem cells. Genes Dev. 2009, 23, 2134-2139.

35. Utikal, J.; Polo, J.M.; Stadtfeld, M.; Maherali, N.; Kulalert, W.; Walsh, R.M.; Khalil, A.; Rheinwald, J.G.; Hochedlinger, K. Immortalization eliminates a roadblock during cellular reprogramming into iPS cells. Nature 2009, 460, 1145-1148.

36. Huntly, B.J.; Shigematsu, H.; Deguchi, K.; Lee, B.H.; Mizuno, S.; Duclos, N.; Rowan, R.; Amaral, S.; Curley, D.; Williams, I.R.; Akashi, K.; Gilliland, D.G. MOZ-TIF2, but not BCR-ABL, confers properties of leukemic stem cells to committed murine hematopoietic progenitors. Cancer Cell 2004, 6, 587-596.

37. Krivtsov, A.V.; Twomey, D.; Feng, Z.; Stubbs, M.C.; Wang, Y.; Faber, J.; Levine, J.E.; Wang, J.; Hahn, W.C.; Gilliland, D.G.; Golub, T.R.; Armstrong, S.A. Transformation from committed progenitor to leukaemia stem cell initiated by MLL-AF9. Nature 2006, 442, 818-822.

38. Morel, A.P.; Lievre, M.; Thomas, C.; Hinkal, G.; Ansieau, S.; Puisieux, A. Generation of breast cancer stem cells through epithelial-mesenchymal transition. PLoS One 2008, 3, e2888.

39. Zongaro, S.; de Stanchina, E.; Colombo, T.; D'Incalci, M.; Giulotto, E.; Mondello, C. Stepwise neoplastic transformation of a telomerase immortalized fibroblast cell line. Cancer Res. 2005, 65, 11411-11418.

40. Boehm, J.S.; Hahn, W.C. Understanding transformation: progress and gaps. Curr. Opin. Genet. Dev. 2005, 15, 13-17.

41. Polyak, K.; Weinberg, R.A. Transitions between epithelial and mesenchymal states: acquisition of malignant and stem cell traits. Nat. Rev. Cancer 2009, 9, 265-273.

42. Mani, S.A.; Guo, W.; Liao, M.J.; Eaton, E.N.; Ayyanan, A.; Zhou, A.Y.; Brooks, M.; Reinhard, F.; Zhang, C.C.; Shipitsin, M.; Campbell, L.L.; Polyak, K.; Brisken, C.; Yang, J.; Weinberg, R.A. The epithelial-mesenchymal transition generates cells with properties of stem cells. Cell 2008, 133, 704-715.

43. Gupta, P.B.; Chaffer, C.L.; Weinberg, R.A. Cancer stem cells: mirage or reality? Nat. Med. 2009, 15, 1010-1012.

44. Al-Hajj, M.; Becker, M.W.; Wicha, M.; Weissman, I.; Clarke, M.F. Therapeutic implications of cancer stem cells. Curr. Opin. Genet. Dev. 2004, 14, 43-47.

45. Greaves, M. Cancer stem cells: back to Darwin? Semin. Cancer Biol. 2010, 20, 65-70.

46. Jordan, C.T. Cancer stem cells: Controversial or just misunderstood? Cell Stem Cell 2009, 4, 203-205. 
47. Masters, J.R. Human cancer cell lines: fact and fantasy. Nat. Rev. Mol. Cell. Biol. 2000, 1, 233-236.

48. van Staveren, W.C.; Solis, D.Y.; Hebrant, A.; Detours, V.; Dumont, J.E.; Maenhaut, C. Human cancer cell lines: Experimental models for cancer cells in situ? For cancer stem cells? Biochim. Biophys. Acta 2009, 1795, 92-103.

49. Kondo, T.; Setoguchi, T.; Taga, T. Persistence of a small subpopulation of cancer stem-like cells in the C6 glioma cell line. Proc. Natl. Acad. Sci. USA 2004, 101, 781-786.

50. Lee, J.; Kotliarova, S.; Kotliarov, Y.; Li, A.; Su, Q.; Donin, N.M.; Pastorino, S.; Purow, B.W.; Christopher, N.; Zhang, W.; Park, J.K.; Fine, H.A. Tumor stem cells derived from glioblastomas cultured in bFGF and EGF more closely mirror the phenotype and genotype of primary tumors than do serum-cultured cell lines. Cancer Cell 2006, 9, 391-403.

51. Yu, F.; Yao, H.; Zhu, P.; Zhang, X.; Pan, Q.; Gong, C.; Huang, Y.; Hu, X.; Su, F.; Lieberman, J.; Song, E. let-7 regulates self renewal and tumorigenicity of breast cancer cells. Cell 2007, 131, 1109-1123.

52. Christgen, M.; Ballmaier, M.; Bruchhardt, H.; von Wasielewski, R.; Kreipe, H.; Lehmann, U. Identification of a distinct side population of cancer cells in the Cal-51 human breast carcinoma cell line. Mol. Cell. Biochem. 2007, 306, 201-212.

53. Kasper, S. Identification, characterization, and biological relevance of prostate cancer stem cells from clinical specimens. Urol. Oncol. 2009, 27, 301-303.

54. Gasparini, P.; Bertolini, G.; Binda, M.; Magnifico, A.; Albano, L.; Tortoreto, M.; Pratesi, G.; Facchinetti, F.; Abolafio, G.; Roz, L.; Tagliabue, E.; Daidone, M.G.; Sozzi, G. Molecular cytogenetic characterization of stem-like cancer cells isolated from established cell lines. Cancer Lett. 2010, 296, 206-215.

55. Honoki, K.; Fujii, H.; Kubo, A.; Kido, A.; Mori, T.; Tanaka, Y.; Tsujiuchi, T. Possible involvement of stem-like populations with elevated ALDH1 in sarcomas for chemotherapeutic drug resistance. Oncol. Rep. 2010, 24, 501-505.

56. Li, G.; Liu, C.; Yuan, J.; Xiao, X.; Tang, N.; Hao, J.; Wang, H.; Bian, X.; Deng, Y.; Ding, Y. $\mathrm{CD} 133(+)$ single cell-derived progenies of colorectal cancer cell line SW480 with different invasive and metastatic potential. Clin. Exp. Metastas. 2010, 27, 517-527.

57. Louie, E.; Nik, S.; Chen, J.S.; Schmidt, M.; Song, B.; Pacson, C.; Chen, X.F.; Park, S.; Ju, J.; Chen, E.I. Identification of a stem-like cell population by exposing metastatic breast cancer cell lines to repetitive cycles of hypoxia and reoxygenation. Breast Cancer Res. 2010, 12, R94.

58. Newton, T.C.; Wolcott, K.; Roberts, S.S. Comparison of the side populations in pretreatment and postrelapse neuroblastoma cell lines. Transl. Oncol. 2010, 3, 246-251.

59. Perego, M.; Tortoreto, M.; Tragni, G.; Mariani, L.; Deho, P.; Carbone, A.; Santinami, M.; Patuzzo, R.; Mina, P.D.; Villa, A.; Pratesi, G.; Cossa, G.; Perego, P.; Daidone, M.G.; Alison, M.R.; Parmiani, G.; Rivoltini, L.; Castelli, C. Heterogeneous phenotype of human melanoma cells with in vitro and in vivo features of tumor-initiating cells. J. Invest. Dermatol. 2010, 130, 1877-1886.

60. Sajithlal, G.B.; Rothermund, K.; Zhang, F.; Dabbs, D.J.; Latimer, J.J.; Grant, S.G.; Prochownik, E.V. Permanently blocked stem cells derived from breast cancer cell lines. Stem Cells 2010, 28, 1008-1018. 
61. Shi, M.F.; Jiao, J.; Lu, W.G.; Ye, F.; Ma, D.; Dong, Q.G.; Xie, X. Identification of cancer stem cell-like cells from human epithelial ovarian carcinoma cell line. Cell. Mol. Life Sci. 2010, 67, 3915-3925.

62. Yeung, T.M.; Gandhi, S.C.; Wilding, J.L.; Muschel, R.; Bodmer, W.F. Cancer stem cells from colorectal cancer-derived cell lines. Proc. Natl. Acad. Sci. USA 2010, 107, 3722-3727.

63. Zhong, Y.; Guan, K.; Guo, S.; Zhou, C.; Wang, D.; Ma, W.; Zhang, Y.; Li, C.; Zhang, S. Spheres derived from the human SK-RC-42 renal cell carcinoma cell line are enriched in cancer stem cells. Cancer Lett. 2010, 299, 150-160.

64. Wang, L.; Park, P.; Lin, C.Y. Characterization of stem cell attributes in human osteosarcoma cell lines. Cancer Biol. Ther. 2009, 8, 543-552.

65. Yang, M.; Zhang, R.; Yan, M.; Ye, Z.; Liang, W.; Luo, Z. Detection and characterization of side population in Ewing's sarcoma SK-ES-1 cells in vitro. Biochem. Biophys. Res. Commun. 2010, 391, 1062-1066.

66. Zhang, L.; Yang, S.; He, Y.J.; Shao, H.Y.; Wang, L.; Chen, H.; Gao, Y.J.; Qing, F.X.; Chen, X.C.; Zhao, L.Y.; Tan, S. Fluorouracil selectively enriches stem-like leukemic cells in a leukemic cell line. Int. J. Biol. Sci. 2010, 6, 419-427.

67. Bunting, K.D. ABC transporters as phenotypic markers and functional regulators of stem cells. Stem Cells 2002, 20, 11-20.

68. Calcagno, A.M.; Salcido, C.D.; Gillet, J.P.; Wu, C.P.; Fostel, J.M.; Mumau, M.D.; Gottesman, M.M.; Varticovski, L.; Ambudkar, S.V. Prolonged drug selection of breast cancer cells and enrichment of cancer stem cell characteristics. J. Nat. Cancer Inst. 2010, 102, 1637-1652.

69. Hirata, N.; Sekino, Y.; Kanda, Y. Nicotine increases cancer stem cell population in MCF-7 cells. Biochem. Biophys. Res. Commun. 2010, 403, 138-143.

70. Stylianou, S.; Clarke, R.B.; Brennan, K. Aberrant activation of notch signaling in human breast cancer. Cancer Res. 2006, 66, 1517-1525.

71. Slamon, D.J.; Clark, G.M.; Wong, S.G.; Levin, W.J.; Ullrich, A.; McGuire, W.L. Human breast cancer: correlation of relapse and survival with amplification of the HER-2/neu oncogene. Science 1987, 235, 177-182.

72. Slamon, D.J.; Godolphin, W.; Jones, L.A.; Holt, J.A.; Wong, S.G.; Keith, D.E.; Levin, W.J.; Stuart, S.G.; Udove, J.; Ullrich, A.; et al. Studies of the HER-2/neu proto-oncogene in human breast and ovarian cancer. Science 1989, 244, 707-712.

73. Shak, S. Overview of the trastuzumab (Herceptin) anti-HER2 monoclonal antibody clinical program in HER2-overexpressing metastatic breast cancer. Herceptin Multinational Investigator Study Group. Semin. Oncol. 1999, 26, 71-77.

74. Tokuda, Y.; Suzuki, Y.; Saito, Y.; Umemura, S. The role of trastuzumab in the management of HER2-positive metastatic breast cancer: an updated review. Breast Cancer 2009, 16, 295-300.

75. Kruser, T.J.; Wheeler, D.L. Mechanisms of resistance to HER family targeting antibodies. Exp. Cell Res. 2010, 316, 1083-1100.

76. Lin, S.X.; Chen, J.; Mazumdar, M.; Poirier, D.; Wang, C.; Azzi, A.; Zhou, M. Molecular therapy of breast cancer: progress and future directions. Nat. Rev. Endocrinol. 2010, 6, 485-493.

77. Ross, J.S. Breast cancer biomarkers and HER2 testing after 10 years of anti-HER2 therapy. Drug News Perspect. 2009, 22, 93-106. 
78. Tagliabue, E.; Balsari, A.; Campiglio, M.; Pupa, S.M. HER2 as a target for breast cancer therapy. Exp. Opin. Biol. Ther. 2010, 10, 711-724.

79. Reim, F.; Dombrowski, Y.; Ritter, C.; Buttmann, M.; Hausler, S.; Ossadnik, M.; Krockenberger, M.; Beier, D.; Beier, C.P.; Dietl, J.; Becker, J.C.; Honig, A.; Wischhusen, J. Immunoselection of breast and ovarian cancer cells with trastuzumab and natural killer cells: selective escape of CD44high/CD24low/HER2low breast cancer stem cells. Cancer Res. 2009, 69, 8058-8066.

80. Magnifico, A.; Albano, L.; Campaner, S.; Delia, D.; Castiglioni, F.; Gasparini, P.; Sozzi, G.; Fontanella, E.; Menard, S.; Tagliabue, E. Tumor-initiating cells of HER2-positive carcinoma cell lines express the highest oncoprotein levels and are sensitive to trastuzumab. Clin. Cancer Res. 2009, 15, 2010-2021.

81. Ma, L.; Lai, D.; Liu, T.; Cheng, W.; Guo, L. Cancer stem-like cells can be isolated with drug selection in human ovarian cancer cell line SKOV3. Acta Biochim. Biophys. Sin. (Shanghai) 2010, 42, 593-602.

82. Bapat, S.A. Human ovarian cancer stem cells. Reproduction 2010, 140, 33-41.

83. Achanzar, W.E.; Brambila, E.M.; Diwan, B.A.; Webber, M.M.; Waalkes, M.P. Inorganic arseniteinduced malignant transformation of human prostate epithelial cells. J. Nat. Cancer Inst. 2002, 94, 1888-1891.

84. Benbrahim-Tallaa, L.; Waalkes, M.P. Inorganic arsenic and human prostate cancer. Environ. Health Perspect. 2008, 116, 158-164.

85. Tokar, E.J.; Qu, W.; Liu, J.; Liu, W.; Webber, M.M.; Phang, J.M.; Waalkes, M.P. Arsenic-specific stem cell selection during malignant transformation. J. Nat. Cancer Inst. 2010, 102, 638-649.

86. Levina, V.; Marrangoni, A.M.; DeMarco, R.; Gorelik, E.; Lokshin, A.E. Drug-selected human lung cancer stem cells: cytokine network, tumorigenic and metastatic properties. PLoS One 2008, 3, e3077.

87. Charafe-Jauffret, E.; Ginestier, C.; Iovino, F.; Wicinski, J.; Cervera, N.; Finetti, P.; Hur, M.H.; Diebel, M.E.; Monville, F.; Dutcher, J.; et al. Breast cancer cell lines contain functional cancer stem cells with metastatic capacity and a distinct molecular signature. Cancer Res. 2009, 69, $1302-1313$.

88. Ginestier, C.; Liu, S.; Diebel, M.E.; Korkaya, H.; Luo, M.; Brown, M.; Wicinski, J.; Cabaud, O.; Charafe-Jauffret, E.; Birnbaum, D.; Guan, J.L.; Dontu, G.; Wicha, M.S. CXCR1 blockade selectively targets human breast cancer stem cells in vitro and in xenografts. J. Clin. Invest. 2010, 120, 485-497.

89. Villano, J.L.; Seery, T.E.; Bressler, L.R. Temozolomide in malignant gliomas: current use and future targets. Cancer Chemother. Pharmacol. 2009, 64, 647-655.

90. Chua, C.; Zaiden, N.; Chong, K.H.; See, S.J.; Wong, M.C.; Ang, B.T.; Tang, C. Characterization of a side population of astrocytoma cells in response to temozolomide. J. Neurosurg. 2008, 109, $856-866$.

91. Kaneko, Y.; Sakakibara, S.; Imai, T.; Suzuki, A.; Nakamura, Y.; Sawamoto, K.; Ogawa, Y.; Toyama, Y.; Miyata, T.; Okano, H. Musashil: An evolutionally conserved marker for CNS progenitor cells including neural stem cells. Dev. Neurosci. 2000, 22, 139-153. 
92. Jin, F.; Zhao, L.; Guo, Y.J.; Zhao, W.J.; Zhang, H.; Wang, H.T.; Shao, T.; Zhang, S.L.; Wei, Y.J.; Feng, J.; Jiang, X.B.; Zhao, H.Y. Influence of Etoposide on anti-apoptotic and multidrug resistance-associated protein genes in CD133 positive U251 glioblastoma stem-like cells. Brain Res. 2010, 1336, 103-111.

93. Giansanti, V.; Donà, F.; Tillhon, M.; Scovassi, A.I. PARP inhibitors: new tools to protect from inflammation. Biochem. Pharmacol. 2010, 80, 1869-1877.

94. Megnin-Chanet, F.; Bollet, M.A.; Hall, J. Targeting poly(ADP-ribose) polymerase activity for cancer therapy. Cell. Mol. Life Sci. 2010, 67, 3649-3662.

95. Rouleau, M.; Patel, A.; Hendzel, M.J.; Kaufmann, S.H.; Poirier, G.G. PARP inhibition: PARP1 and beyond. Nat. Rev. Cancer 2010, 10, 293-301.

96. Villanueva, T. Expanding the horizons of PARP inhibitors. Nat. Rev. Cancer 2010, 10, 814.

97. Drew, Y.; Plummer, R. PARP inhibitors in cancer therapy: two modes of attack on the cancer cell widening the clinical applications. Drug Resist. Updat. 2009, 12, 153-156.

98. Patel, A.; Kaufmann, S.H. Development of PARP inhibitors: an unfinished story. Oncology (Williston Park) 2010, 24, 66-68.

99. Di Fiore, R.; Santulli, A.; Ferrante, R.D.; Giuliano, M.; De Blasio, A.; Messina, C.; Pirozzi, G.; Tirino, V.; Tesoriere, G.; Vento, R. Identification and expansion of human osteosarcoma-cancerstem cells by long-term 3-aminobenzamide treatment. J. Cell. Physiol. 2009, 219, 301-313.

100. Liu, E.H.; Qi, L.W.; Wu, Q.; Peng, Y.B.; Li, P. Anticancer agents derived from natural products. Mini Rev. Med. Chem. 2009, 9, 1547-1555.

101. Subramaniam, D.; Ramalingam, S.; Houchen, C.W.; Anant, S. Cancer stem cells: a novel paradigm for cancer prevention and treatment. Mini Rev. Med. Chem. 2010, 10, 359-371.

102. Epstein, J.; Sanderson, I.R.; Macdonald, T.T. Curcumin as a therapeutic agent: the evidence from in vitro, animal and human studies. Br. J. Nutr. 2010, 103, 1545-1557.

103. Fong, D.; Yeh, A.; Naftalovich, R.; Choi, T.H.; Chan, M.M. Curcumin inhibits the side population (SP) phenotype of the rat C6 glioma cell line: towards targeting of cancer stem cells with phytochemicals. Cancer Lett. 2010, 293, 65-72.

104. Guzman, M.L.; Rossi, R.M.; Karnischky, L.; Li, X.; Peterson, D.R.; Howard, D.S.; Jordan, C.T. The sesquiterpene lactone parthenolide induces apoptosis of human acute myelogenous leukemia stem and progenitor cells. Blood 2005, 105, 4163-4169.

105. Zhou, J.; Zhang, H.; Gu, P.; Bai, J.; Margolick, J.B.; Zhang, Y. NF-kappaB pathway inhibitors preferentially inhibit breast cancer stem-like cells. Breast Cancer Res. Treat. 2008, 111, 419-427.

106. Kim, J.B.; Ko, E.; Han, W.; Shin, I.; Park, S.Y.; Noh, D.Y. Berberine diminishes the side population and ABCG2 transporter expression in MCF-7 breast cancer cells. Planta Med. 2008, 74, 1693-1700.

107. Bar, E.E.; Chaudhry, A.; Lin, A.; Fan, X.; Schreck, K.; Matsui, W.; Piccirillo, S.; Vescovi, A.L.; DiMeco, F.; Olivi, A.; Eberhart, C.G. Cyclopamine-mediated hedgehog pathway inhibition depletes stem-like cancer cells in glioblastoma. Stem Cells 2007, 25, 2524-2533.

108. Hirsch, H.H.; Iliopoulus, D.; Tsichlis, P.N.; Struhl, K. Metformin selectively targets cancer stem cells, and acts together with chemotherapy to block tumor growth and prolong remission. Cancer Res. 2009, 69, 7507-7511. 
109. Martin-Castillo, B.; Vazquez-Martin, A.; Oliveras-Ferraros, C.; Menendez, J.A. Metformin and cancer. Cell Cycle 2010, 9, 1057-1064.

(C) 2011 by the authors; licensee MDPI, Basel, Switzerland. This article is an open access article distributed under the terms and conditions of the Creative Commons Attribution license (http://creativecommons.org/licenses/by/3.0/). 